\title{
COMPARATIVE ANALYSIS OF RISK AND RETURN IN PT. BANK BRI SYARIAH BEFORE AND AFTER SPIN OFF
}

\author{
Siti Ratna Sari ${ }^{1}$, Darwis Harahap ${ }^{2}$, Azwar Hamid ${ }^{3}$, Rahmat Annam ${ }^{4}$ \\ ${ }^{1}$ IAIN Padangsidimpuan (Perbankan Syariah, FEBI, IAIN Padangsidimpuan) \\ ${ }^{2}$ IAIN Padangsidimpuan (Perbankan Syariah, FEBI, IAIN Padangsidimpuan) \\ ${ }^{3}$ IAIN Padangsidimpuan (Perbankan Syariah, FEBI, IAIN Padangsidimpuan) \\ ${ }^{4}$ IAIN Padangsidimpuan (Ekonomi Syariah Syariah, FEBI, IAIN Padangsidimpuan) \\ sitiratnasari@gmail.com ${ }^{1}$, darwisharahap@iain-padangsidimpuan.ac.id ${ }^{2}$, azwarhamid@iain- \\ padangsidimpuan.ac.id ${ }^{3}, \underline{\text { rahmatannam@iain-padangsidimpuan.ac.id }}^{4}$
}

\begin{abstract}
ABSTRAK
PT. Bank BRI Syariah merupakan salah satu bank yang melakukan pemisahan/ spin off dengan tujuan untuk memperoleh laba (profit). Peneliti menggunakan rasio FDR untuk menilai risk dan rasio ROA untuk menilai return pada PT. Bank BRI Syariah sebelum dan sesudah spin off. Nilai rasio FDR sebelum dan sesudah spin off mengalami fluktuasi namun laba bersih terus mengalami peningkatan begitu juga dengan nilai rasio ROA sebelum dan sesudah spin off mengalami fluktuasi sedangkan laba bersih terus meningkat dari tahun ke tahun. Rumusan masalah dalam penelitian ini adalah apakah terdapat perbedaan risk dan return pada PT. Bank BRI Syariah sebelum dan sesudah spin off. Tujuan penelitian ini adalah untuk menganalisa perbedaan risk dan return sebelum dan sesudah spin off. Penelitian ini merupakan penelitian kuantitatif. Teknik pengumpulan data yang digunakan adalah studi kepustakaan dan dokumentasi, melalui situs resmi PT. BRI Syariah yaitu www.brisyariah.co.id dan Otoritas Jasa Keuangan yaitu www.ojk.go.id. Teknik analisa data menggunakan analisis deskriptif, uji normalitas, uji sample paired t-test. Proses pengolahan data dengan menggunakan program komputer yaitu SPSS versi 22.0 Hasil uji statistik sample paired t-test menunjukkan bahwa terdapat perbedaan risk (risiko) PT. Bank BRI Syariah sebelum dan sesudah spin off jika diukur menggunakan Financing to Deposit Ratio (FDR), dengan nilai $t_{\text {hitung }}$ sebesar 5,288 dan nilai $t_{\text {tabel }}$ sebesar 1,70329 (5,288 > 1,70329). Hasil uji statistik sample paired t-test menunjukkan bahwa terdapat perbedaan return PT. Bank BRI Syariah sebelum dan sesudah spin off jika diukur menggunakan Return On Aset (ROA), dengan nilai $t_{\text {hitung }}$ sebesar 15,318 dan nilai $t_{\text {tabel }}$ sebesar 1,70329 (15,318 > 1,70329).
\end{abstract}

Kata Kunci: Risk, Return, Spin Off dan PT.Bank BRI Syariah

\begin{abstract}
PT. Bank BRI Syariah is one of the banks that performs a spin-off with the aim of making a profit. Researchers use the FDR ratio to assess risk and ROA ratio to assess return at PT. BRI Syariah Bank before and after the spin off. The value of the FDR ratio before and after the spin off fluctuated but net income continued to increase as well as the value of the ROA ratio before and after the spin off fluctuated while net income continued to increase from year to year. The formulation of the problem in this study is whether there are differences in risk and return at PT. BRI Syariah Bank before and after the spin off. The purpose of this study was to analyze the difference in risk and return before and after the spin off. This research is a quantitative research. The data collection technique used is
\end{abstract}


literature study and documentation, through the official website of PT. BRI Syariah, namely www.brisyariah.co.id and the Financial Services Authority, namely www.ojk.go.id. The data analysis technique used descriptive analysis, normality test, sample paired t-test. The data processing process using a computer program, namely SPSS version 22.0. The statistical test results of the paired t-test sample indicate that there are differences in risk (risk) of PT. BRI Syariah Bank before and after the spin off if measured using the Financing to Deposit Ratio (FDR), with a $t_{\text {count }}$ value of 5.288 and a $t_{\text {table }}$ value of $1.70329(5.288>1.70329)$. The results of the statistical test of the paired t-test showed that there were differences in the return of PT. BRI Syariah Bank before and after the spin off if measured using Return On Assets (ROA), with a $t_{\text {count }}$ value of 15.318 and a $t_{\text {table }}$ value of 1.70329 (15.318 > 1.70329).

Keywords: Risk, Return, Spin Off and PT. Bank BRI Syariah

\section{A. PENDAHULUAN}

Bank Syariah di Indonesia telah muncul semenjak tahun 1992. Dalam menghadapi perkembangan perekonomian yang senantiasa berubah, maka perbankan syariah Indonesia yang berada dalam tahap awal pertumbuhan, masih memiliki kesempatan untuk melakukan tindakan dalam rangka mewujudkan perbankan syariah yang sehat. Sehubung dengan upaya pengembangan perbankan syariah. Pemerintah telah mengundangkan Undang-Undang Nomor 10 Tahun 1998. Undang-Undang ini secara substansial mengatur tentang dual banking system dalam pengembangan kegiatan perbankan di Indonesia.

Kinerja sebuah perusahaan adalah suatu ukuran yang menggambarkan kondisi keuangan perusahaan. Kinerja perusahaan sangat menentukan bagi preferensi masyarakat baik stake holder maupun bond holder untuk melakukan investasi sangat ditentukan oleh kinerja perusahaan.
Kinerja perusahaan umumnya diukur berdasarkan penghasilan bersih atau laba. Jadi dapat disimpulkan laba dapat menggambarkan kinerja bank karena dengan laba yang terus meningkat menunjukkan kepada pihak yang berkepentingan bahwa bank teresbut mampu menjalankan fungsinya yaitu memperoleh laba dari kegiatan usaha dengan menggunakan modal bank tersebut.

Bank bertujuan untuk memperoleh laba (profit). Maka wajar apabila profitabilitas menjadi perhatian utama para analisis dan investor. Tingkat profitabilitas yang konsisten atau memperoleh laba yang maksimal akan menjadi tolak ukur bagaimana bank tersebut mampu bertahan dalam bisnisnya dengan memperoleh return yang memadai dibanding dengan risikonya.

Berawal dari akuisisi PT. Bank Rakyat Indonesia (Persero), Tbk., terhadap Bank Jasa Arta Pada 19 Desember 2007 dan setelah mendapatkan izin dari Bank Indonesia pada 16 Oktober 2008 melalui suratnya 
No.10/67/KEP.GBI/DpG/2008, maka pada tanggal 17 November 2008 PT. Bank BRI Syariah Tbk secara resmi beroperasi. Kemudian PT. Bank BRI Syariah Tbk merubah kegiatan usaha yang semula beroperasional secara konvensional, kemudian diubah menjadi kegiatan perbankan berdasarkan prinsip syariah Islam. Aktivitas PT Bank BRI Syariah Tbk semakin kokoh setelah pada 19 Desember 2008 ditandatangani akta pemisahan Unit Usaha Syariah PT. Bank Rakyat Indonesia (Persero), Tbk., untuk melebur ke dalam PT. Bank BRI Syariah Tbk (proses spin off) yang berlaku efektif pada tanggal 1 Januari 2009.

Penandatanganan dilakukan oleh Bapak Sofyan Basir selaku Direktur Utama PT. Bank Rakyat Indonesia (Persero), Tbk., dan Bapak Ventje Rahardjo selaku Direktur Utama PT. Bank BRI Syariah Tbk. Saat ini PT. Bank BRI Syariah Tbk menjadi bank syariah ketiga terbesar setelah Bank Mandiri Syariah dan Bank Muamalat Indonesia berdasarkan aset.

Laba bersih PT. Bank BRI Syariah sebelum dan sesudah spin off periode tahun 2006 sampai 2015 mengalami fluktuasi seperti gambar dibawah ini:

Gambar I.1

Perkembangan Laba PT. Bank BRI Syariah sebelum dan sesudah Spin Off

(Dalam Triliun Rupiah)

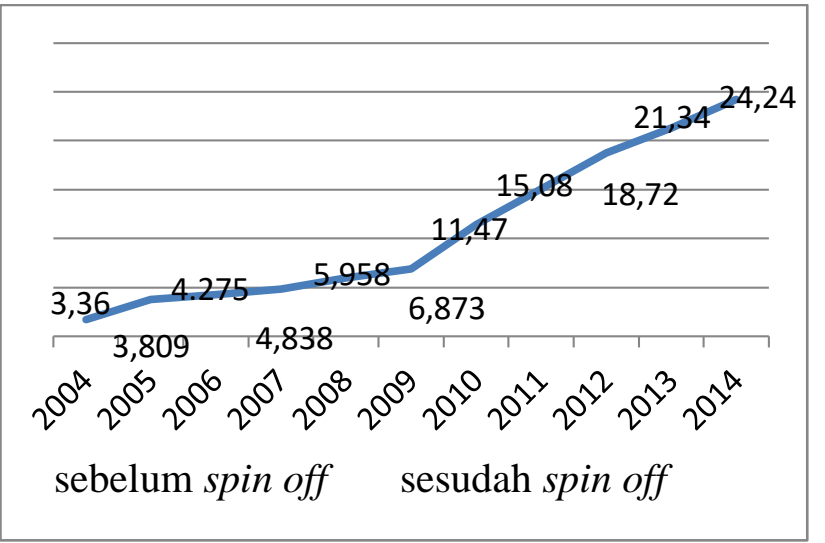

Sumber :www.brisyariah.co.id

Berdasarkan gambar di atas, perkembangan laba bersih PT. Bank BRI Syariah sebelum spin off sebesar Rp. 3,36 pada tahun 2004, kemudian pada tahun 2005 meningkat sebesar 0,449 persen menjadi Rp. 3,809. Pada tahun 2006 kembali meningkat sebesar 0,448 persen menjadi Rp. 4,275. Pada tahun 2007 meningkat lagi sebesar 0,581 pesren menjadi Rp. 4,838 dan kembali meningkat sebesar 1,12 menjadi 5,958 pada tahun 2008. Kemudian pada tahun 2009 setelah melakukan spin off laba bersih mengalami kenaikan sebesar 0,915 persen menjadi Rp.6,873. Pada tahun 2010 laba meningkat sebesar 4,597 persen menjadi Rp.3,61 dan meningkat lagi sebesar 3,64 persen menjadi Rp.15,08 pada tahun 2011. Kemudian pada tahun 2012 meningkat sebesar 2,62 persen menjadi Rp.21,34 dan meningkat lagi sebesar 2,9 persen menjadi Rp. 24,24 pada tahun 2015.

Dalam penelitian ini, peneliti menggunakan rasio likuiditas untuk menilai risk PT. Bank BRI Syariah sebelum dan sesudah spin off, dan menggunakan rasio rentabilitas untuk 
menilai return PT. Bank BRI Syariah sebelum dan sesudah spin off.

Rasio likuiditas merupakan rasio yang menggambarkan kemampuan perusahaan dalam memenuhi kewajiban jangka pendek (Fred Weston). Fungsi rasio likuiditas adalah untuk menunjukkan atau mengukur kemampuan perusahaan dalam memenuhi kewajibannya yang jatuh tempo, baik kewajiban kepada pihak luar perusahaan (likuiditas badan usaha) maupun di dalam perusahaan (likuiditas perusahaan). Salah satu rasio likuiditas bank, yaitu Financing to Deposit Ratio (FDR). Financing to Deposit Ratio (FDR) merupakan rasio yang digunakan untuk mengukur komposisi jumlah pembiayaan yang diberikan dibandingkan dengan jumlah deposan.

Financing to Deposit Ratio (FDR) PT. Bank BRI Syariah sebelum dan sesudah spin off dari tahun ke tahun juga mengalami fluktuasi seperti gambar dibawah ini.

Gambar 1.2

Financing to Deposit Ratio PT. Bank BRI Syariah Sebelum dan Sesudah Spin Off

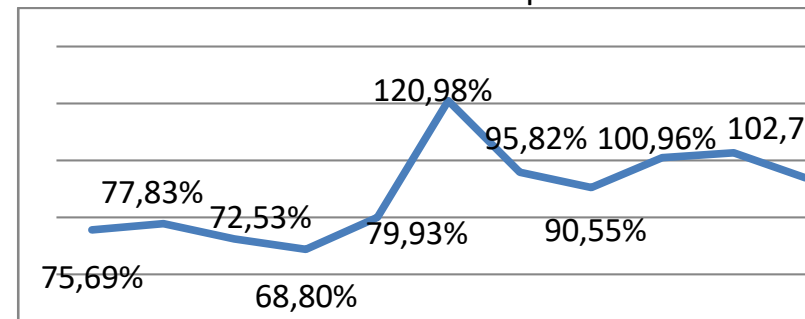

200420052006200720082009201020112012201320 sebelum spin off sesudah spin off

Sumber : wwwbrisyariah.co.id
POINT Vol. 1, No. 2, Des 2020

Rasio FDR PT. Bank BRI Syariah sebelum dan sesudah spin off dari tahun ke tahun mengalami fluktuasi. Pada tahun 2004 rasio FDR sebesar 75,69 persen meningkat sebesar 2,14 persen menjadi 77,83 persen dan mengalami penurunan sebesar 5,3 persen menjadi 72,53 persen pada tahun 2006. Kemudian pada tahun 2007 mengalami penurunan kembali sebesar 3,73 persen menjadi 68,80 persen dan meningkat kembali sebesar 11,13 persen menjadi 79,93 persen pada tahun 2008 dan juga mengalami peningkatan sebesar 41,05 persen menjadi 120,98 persen pada tahun 2009. Pada tahun pertama spin off rasio FDR berada pada rasio tertiggi dibanding pada tahun sebelum spin off.

Pada tahun 2009 pertama spin off rasio FDR meningkat sebesar 41,05 persen menjadi 120,98 persen. Kemudian pada tahun 2011 menurun sebesar 25,16 persen menjadi 95,82 persen dan meningkat kembali sebesar 10,41 persen menjadi 100,96 persen pada tahun 2012 kemudian meningkat sebesar 1,74 persen menjadi 102,70 persen pada tahun 2013. Pada tahun 2014 rasio FDR kembali mengalami penurunan sebesar 8,8 persen menjadi 93,90 persen pada tahun 2014

Bank wajib menyediakan likuiditas dengan cukup dan mengelolanya dengan baik, jika likuiditas terlalu kecil maka akan mengganggu kegiatan operasional bank. Namun, likuiditas yang terlalu besar akan menurunkan efisiensi bank sehingga 
berdampak pada rendahnya tingkat profitabilitas.

Dari gambar 1.2 tersebut terlihat bahwa perolehan FDR pada PT. Bank BRI Syariah sebelum dan sesudah spin off mengalami fluktuasi dari tahun ke tahun. Pada tahun 2005 rasio FDR sebelum spin off sebesar 77,83 persen namun laba naik sebesar 3,809 persen kemudian rasio FDR menurun sebesar 72,53 persen namun laba terus meningkat sebesar 4,275 persen kemudian pada tahun 2008 rasio FDR bearada pada rasio tertinggi sebesar 79,90 namun laba juga mengalami peningkatan sebesar 5,985. Setelah spin off rasio FDR berada pada rasio paling besar pada tahun 2009 senilai 120,98 persen, namun laba juga meningkat menjadi 6,873 persen. Kemudian FDR menurun sebesar 95,82 persen namun laba terus meningkat sebesar 11,47 persen.

Selain memperhatikan rasio likuiditas, bank syariah juga perlu memperhatikan return yang dilihat dengan rasio rentabilitas. Rasio rentabilitas merupakan rasio yang digunakan untuk mengukur tingkat efisiensi usaha dan profitabilitas yang dicapai oleh bank yang bersangkutan. Mengukur rasio keuangan perusahaan, dengan alat ukur yang biasa digunakan untuk mengukur tingkat laba (profitabilitas) adalah Return On Aset (ROA).

Return On Aset (ROA) merupakan bagian dari rasio profitabilitas yaitu gambaran tentang kemampuan bank dalam menghasilkan laba bagi suatu perusahaan. Dimana ROA pada bank syariah menggambarkan kemampuan bank mengelola dana yang diinvestasikan dalam keseluruhan aktiva yang menghasilkan keuntungan. ROA adalah gambaran produktivitas bank dalam mengelola dana sehingga menghasilkan keuntungan.

Return On Aset PT. Bank BRI Syariah dari tahun ke tahun juga mengalami fluktuasi seperti pada gambar dibawah ini.

Gambar I.3

Return On Aset PT. Bank BRI Syariah Sebelum dan Sesudah Spin Off

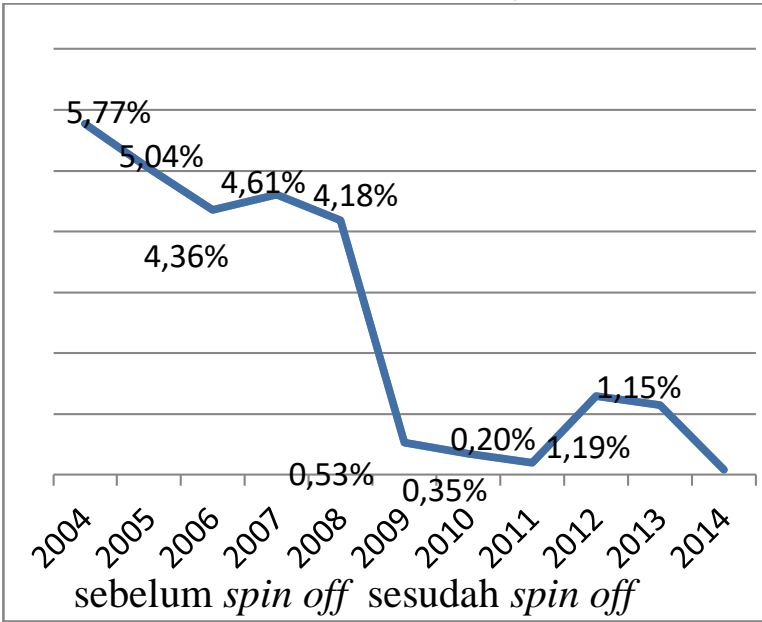

Sumber :wwwbrisyariah.co.id

Rasio ROA PT. Bank BRI Syariah sebelum dan sesudah spin off mengalami fluktuasi dari tahun ke tahun. Pada tahun 2004 rasio ROA sebesar 5,77 persen menurun sebesar 0,73 persen menjadi 5,04 persen pada tahun 2005. Kemudian menurun kembali sebesar 0,68 persen menjadi 4,36 persen pada tahun 2006. Pada tahun 2007 mengalami peningkatan sebesar 0,25 persen menjadi 4,61 persen dan mengalami peningkatan sebesar 0,43 persen menjadi 4,18 persen pada tahun 2008. 
Siti Ratna Sari ${ }^{1}$, Darwis Harahap ${ }^{2}$, Azwar Hamid ${ }^{3}$, Rahmat Annam ${ }^{4}$

Pada tahun 2009 pertama spin off rasio ROA sebesar 0,53 menurun sebesar 0,18 menjadi 0,35 pada tahun 2010. Pada tahun 2011 sebesar 0,20 persen meningkat sebesar 0,99 persen menjadi 1,19 persen pada tahun 2012. Kemudian mengalami penurunan sebesar 0,04 persen menjadi 1,15 persen pada tahun 2013 dan menurun kembali sebesar 1,07 persen menjadi 0,08 persen pada tahun 2014 .

Rasio profitabilitas merupakan salah satu dari bagian rasio keuangan bank yang digunakan untuk melihat bagaimana suatu bank dalam menghasilkan keuntungan atau profit atas seluruh aset yang dimiliki suatu bank. Salah satu indikator yang digunakan dalam mengukur rasio profitabilitas bank adalah Return On Aset (ROA). Jika perolehan ROA terus menurun maka hal ini akan mengakibatkan perolehan profit yang rendah atau menurun bagi bank tersebut, karena ROA merupakan salah satu indikator yang digunakan untuk mengukur kondisi profitabilitas atau hasil pengembalian atas total aktiva yang dimiliki oleh suatu perusahaan.

Dari gambar I.3 tersebut terlihat bahwa perolehan ROA pada PT. Bank BRI Syariah sebelum dan sesudah spin off mengalami fluktuasi dari tahun ke tahun. Namun, peningkatan yang terjadi pada ROA tidak selalu diikuti oleh laba pada bank tersebut, begitu juga sebaliknya, menurunnya ROA juga tidak selalu diikuti dengan menurunnya laba pada bank tersebut.Pada tahun 2004 sebelum spin off rasio ROA sebesar 5,77 persen dan laba sebesar 3,36 persen. Kemudian pada tahun
POINT Vol. 1, No. 2, Des 2020 2005 ROA mengalami penurunan sebesar 0,73 persen menjadi 5,04 sedangkan laba mengalami kenaikan sebesar 0,449 menjadi 3,809 persen.

Setelah spin off pada tahun 2010 rasio ROA sebesar 0,35 persen dan laba sebesar 11,47 persen kemudian ROA mengalami penurunan sebesar 0,15 persen menjadi 0,20 persen sedangkan laba mengalami kenaikan sebesar 11,47 persen. rasio ROA kembali menurun sebesar 0,08 pada tahun 2014 sedangkan laba justru mengalami peningkatan sebesar 24,24 persen pada tahun 2014.

PT. Bank BRI Syariah merupakan salah satu bank yang melakukan pemisahan (Spin Off). Sementara dari laba bersih PT. Bank BRI Syariah mengalami kenaikan setelah melakukan spin off. Perkembangan FDR setelah melakukan spin off mengalami fluktuasi. Sedangkan return yang diukur dengan rasio ROA juga mengalami fluktuasi setelah melakukan spin off.

\section{B. METODE}

Lokasi penelitian dilakukan pada PT. Bank BRI Syariah melalui situs resmi www.brisyariah.co.id, www.bri.co.id dan Otoritas Jasa Keuangan melalui www.ojk.go.id. Penelitian ini dilakukan mulai Mei 2019 sampai dengan September 2019.

Jenis penelitian yang dilakukan peneliti adalah penelitian kuantitatif. Penelitian kuantitatif adalah penelitian ilmiah yang sistematis terhadap bagian-bagian dan fenomena serta hubungan antarbagian dan fenomena tersebut. Tujuan penelitian kuantitatif adalah mengembangkan dan menggunakan model-model matematis, teori-teori, dan atau hipotesis yang berkaitan dengan fenomena alam. Menurut metodenya, penelitian ini 
menggunakan metode komparatif. Penelitian komparatif adalah "penelitian yang dilakukan untuk membandingkan nilai satu variabel dengan variabel lainnya dalam waktu yang berbeda".

Populasi adalah sekumpulan orang atau objek yang memiliki kesamaan dalam satu atau beberapa hal yang membentuk masalah pokok penelitian. Dalam penelitian ini yang menjadi populasinya adalah seluruh laporan keuangan PT. Bank BRI Syariah dan PT. Bank BRI dari tahun 2002 sampai tahun 2018 .

Sampel adalah dari jumlah dan karakteristik yang dimiliki oleh populasi tersebut. Suatu objek atau subjek yang mewakili populasi. Pengambilan sampel harus sesuai dengan kualitas dan karakteristik suatu populasi. Pengambilan sampel yang tidak sesuai dengan kualitas dan karakteristik populasi akan menyebabkan suatu penelitian menjadi bias, tidak dapat depercaya dan kesimpulannya pun bisa keliru. Hal ini karena tidak dapat mewakili populasi.

Adapun teknik sampling pada penelitian ini adalah sampel proporsional. Sampel proporsional adalah sampel yang menunjukkan kepada perbandingan penarikan sampel dari beberapa subpopulasi yang tidak sama jumlahnya.

Berdasarkan teknik sampel proporsional, maka sampel dalam penelitian ini yaitu laporan rasio keuangan PT. Bank BRI dan PT. Bank BRI Syariah triwulan pertama tahun 2002 sampai dengan triwulan keempat tahun 2018. Dengan demikian, sampel yang digunakan dalam penelitian ini berjumlah 68 sampel.

\section{HASIL DAN PEMBAHASAN}

Analisis perbandingan adalah teknik analisis laporan keuangan yang dilakukan dengan cara menyajikan laporan keuangan secara horizontal dan membandingkan antara satu dengan yang lain, dengan menunjukkan informasi keuangan dan data lainnya, baik dalam rupiah ataupun unit. Teknik perbandingan ini dapat menunjukkan kenaikan dan penurunan dalam rupiah ataupun dalam unit juga dalam persentase atau perbandingan dalam bentuk angka perbandingan atau rasio.

Analisis perbandingan yang digunakan dalam penelitian ini melalui rasio likuiditas yaitu FDR dan rasio rentabilitas yaitu ROA. Hasil dari penelitian ini sebagaimana yang telah dicantumkan dalam beberapa tabel diatas yang dianalisis dengan menggunakan SPSS versi 22.0 menunjukkan bahwa:

1. Financing to Deposit Ratio (FDR) sebelum dan sesudah spin off

Rasio Financing to Deposit Ratio (FDR) adalah rasio antara seluruh jumlah kredit (pembiayaan) yang diberikan bank dengan dana yang diterima oleh bank. Rasio ini sangat berpengaruh positif pada tingkat profitabilitas, semakin tinggi rasio ini memberikan indikasi semakin rendahnya kemampuan likuiditas bank yang bersangkutan, hal ini disebabkan karena jumlah dana yang diperlukan untuk membiayai kreditnya semakin banyak sehingga berdampak pada naiknya profitabilitas. Besarnya Financing to Deposit Ratio (FDR) yang dibuat pemerintah maksimum sebesar $110 \%$.

Rasio FDR PT. Bank BRI Syariah sebelum dan sesudah spin off dengan menggunakan uji sample paired t- test menunjukkan adanya perbedaan pada risk (risiko) yang dibuktikan dari nilai thitung $>$ ttabel $(5,288>1,70329)$, dengan kata lain hipotesis diterima. Berdasarkan hasil tersebut kemampuan likuiditas bank sesudah spin off mengalami perbaikan yang cukup signifikan. 
Rata-rata rasio FDR sebelum dan sesudah spin off pada PT. Bank BRI Syariah dapat dilihat pada tabel IV.4 yang menjelaskan bahwa mean dari rasio FDR sebelum spin off sebesar 130,6857 mengalami penurunan dibandingkan sesudah spin off sebesar 94,9533, hal ini dapat disebabkan karena bank dapat mengendalikan pembiayaan atau kredit, aktiva jangka pendek, kas, dan secondary reserve mampu memenuhi kewajiban jangka pendek pada bank sehingga bank mampu memenuhi kebutuhan likuiditas jangka pendeknya. Hal ini sesuai dengan penelitian yang dilakukan oleh Surbaiti dalam penelitiannya yang berjudul "Analisis Tingkat Kesehatan Sebelum dan Sesudah Spin Off (Studi Kasus Pada PT. Bank BRI Syariah) menunjukkan bahwa terdapat perbedaan FDR sebelum dan sesudah spin off. Dan penelitian yang dilakukan oleh Atman Poerwokoesoemo dengan judul 'Kinerja Bank Konvensional Pasca Spin Off (Unit Usaha Syariah)" menunjukkan bahwa terdapat perbedaan LDR setelah melakukan spin off. Sedangkan penelitian yang dilakukan oleh Amalia Nasuha sangat bertolak belakang dengan penelitian ini. Pada penelitian Amalia Nasuha yang berjudul Dampak Kebijakan Spin Off Terhadap Kinerja Bank Syariah menunjukkan tidak terdapat perbedaan pada rasio FDR sebelum dan sesudah spin off.

Induk perusahaan melakukan spin off terhadap anak perusahaan mereka untuk melindungi perusahaan dari risiko tertentu, yang umumnya untuk menstabilkan pendapatan perusahaan induk. Spin off berisiko untuk membiayai ekspansi berdasarkan tarif sendiri pertumbuhan dan proyeksi perusahaan. Spin off dapat menarik investor baru ke perusahaan spin off dan bisa meningkatkan nilai perusahaan induk karena
POINT Vol. 1, No. 2, Des 2020 anak perusahaan induk tidak lagi terkait dengannya.

2. Return On Aset (ROA)

Return On Aset (ROA) adalah rasio untuk mengukur tingkat efektivitas bank dalam mengelola aset. Semakin tinggi rasio ROA menunjukkan kemampuan manajemen perusahaan dalam mengelola aset yang tersedia secara efektif dan efisien.

Rasio ROA PT. Bank BRI Syariah sebelum dan sesudah spin off dengan menggunakan uji sample paired t- test menunjukkan adanya perbedaan pada return yang dibuktikan dari nilai thitung > ttabel $(15,318>1,70329)$, dengan kata lain hipotesis diterima. Berdasarkan hasil tersebut kemampuan rentabilitas bank sesudah spin off mengalami penurunan yang cukup signifikan.

Rata- rata rasio ROA sebelum dan sesudah spin off pada PT. Bank BRI Syariah dapat dilihat pada tabel IV.4 yang menjelaskan bahwa mean dari rasio ROA sebelum spin off sebesar 8,1779 mengalami penurunan setelah spin off menjadi 0,8575 , artinya ROA sebelum spin off lebih baik dibandingkan sesudah spin off hal ini disebabkan perolehan net income dan pengelolaan equity capital.

Hal ini sejalan dengan penelitian yang dilakukan oleh Atman Poerwokoesoemo dengan penelitiannya yang berjudul "kinerja Bank Konvensional Pasca Spin Off Unit Usaha Syariah", dengan menggunakan analisis sample paired ttest menunjukkan bahwa terdapat perbedaan ROA sebelum dan setelah spin off. Diperkuat oleh penelitian Hikma Warni Hutasuhut dengan judul "Analisi Perbandingan Kinerja Keuangan Sebelum Dan Sesudah Go Public (Studi kasus PT. Bank Panin Syariah Tbk)", dengan menggunakan 
metode sample paired test menunjukkan bahwa rasio ROA, CAR, dan BOPO menunjukkan adanya perbedaan sebelum dan sesudah spin off.

Berdasarkan teori, dalam restrukturisasi pelaksanaan spin off, perkembangan bisnis perusahaan hasil spin off ditaggung oleh pemilik baru dari perusahaan tersebut. Dalam membuat keputusan, perusahaan induk harus meyakinkan dan memberi motivasi kepada perusahaan spin off untuk mengambil keputusan dan membuat perusahaan spin off sebagai perusahaan yang sukses.

\section{PENUTUP}

\section{Kesimpulan}

Berdasarkan pengolahan data dan hasil analisis yang mengacu pada masalah dan tujuan penelitian, maka dapat dirumuskan beberapa kesimpulan penelitian sebagai berikut:

1. Hasil uji statistik sample paired t test menunjukkan bahwa terdapat perbedaan risk (risiko) PT. Bank BRI Syariah sebelum dan sesudah spin off jika diukur menggunakan Financing to Deposit Ratio (FDR), dengan nilai thitung sebesar 5,288 dan nilai ttabel sebesar 1,70329 (5,288 > $1,70329)$

2. Hasil uji statistik sample paired $t$ test menunjukkan bahwa terdapat perbedaan return PT. Bank BRI Syariah sebelum dan sesudah spin off jika diukur menggunakan Return On Aset (ROA), dengan nilai thitung sebesar15,318 dan nilai ttabel sebesar $1,70329(15,318>1,70329)$.

\section{Saran}

Semoga adanya pengetahuan masyarakat terhadap minat produk perbankan syariah

\section{DAFTAR PUSTAKA}

Abdul Nasser Hasibuan, Jurnal Imara, "Strategi pemasaran produk funding di PT. Bank pembiayaan rakyat syariah padangsidimpuan", 2018.

Ali Hardana, Jurnal Al Masharif, "Model Pengembangan Kewirausahaan Di Perguruan Tinggi", 2018.

Agus Irianto, Statistik: Konsep Dasar, Aplikasi dan Pengembangannya (Jakarta: Kencana, 2004).

Bambang Hermanto dan Mulyo Agung, Analisis Laporan Keuangan (Jakarta: Lentera IImu Cendekia, 2015).

Boedi Abdullah, Beni Ahmad, Metode Penelitian Ekonomi Islam Muamalah (Bandung: CV. PustakaSetia, 2014).

Burhan Bungin, Metodologi Penelitian Kuantitatif (Jakatra: Prenada Media, 2005).

Darsono \& Ashari, pedoman Praktis Memahami Laporan Keuangan (Yogyakarta: CV Andi Ofsett, 2005).

Departemen Agama RI, Al-Qur'an dan Terjemahnya (Bandung: CV Penerbit Diponegoro, 2005).

Dwi Suwiknyo, Analisis Laporan Keuangan Perbankan Syariah (Jakarta: Ghalia Indonesia, 2005).

Ganjar Isnawan, Akuntansi Praktis untuk UMKM ( Jakarta Timur: Laksa Aksara, 2012). 
Harahap Sofyan Safri, Analisis Kritis Atas Laporan Keuangan (Jakarta: PT. Raja Grafindo Persada, 1999).

Herry Sutanto dan Khaerul Umam, Manajemen Pemasaran Bank Syariah (Bandung: CV. Pustaka Setia, 2013).

Iqbal Hasan, Analisis Data Penelitian dengan Statistik (Jakarta: PT. Bumi Aksara. 2004).

Imam Wahyudi, Manajemen Risiko Bank Islam (Jakarta: Salemba Empat, 2013).

Irham Fahmi, Pengantar Manajemen Keuangan Teori dan Tanya Jawab (Bandung, ALFABETA, 2016).

Ismail, Manajemen Perbankan dari Teori Menuju Aplikasi (Jakarta: Prenada Media Group, 2011).

Jundiani, Pengaturan Hukum Perbankan Syariah di Indonesia (Malang: Press, 2009).

Kasmir, Manajemen Perbankan (Jakarta: Rajawali Pers, 2014).

Analisis Laporan Keuangan (Jakarta:

Rajawali Pers, 2015).

Kasmir dan Jakfar, Studi Kelayakan Bisnis (Jakarta: Kencana Prenada Media Group, 2009).

Khaerul Umam, Manajemen Perbankan Syariah (Bandung: Pustaka Setia, 2013).

Khotibul Umam dan Veri Antoni, Corporate Action Pembentukan Bank Syariah (Akuisisi, Konversi, dan Spin Off), (Yogyakarta: Gadjah Mada University Press, 2014)

Lukman Dendawijaya, Manajemen Perbankan (Yogyakarta: CAPS, 2015).

Mudjarat Kuncoro, Metode Riset Untuk Bisnis dan Ekonomi Edisi 3 (Jakarta: Erlangga, 2009).
POINT Vol. 1, No. 2, Des 2020

Muhammad, Metodologi Penelitian Ekonomi Islam Pendekatan Kuantitatif (Jakarta: PT. Rajawali Pers, 2008)

, Manajemen Dana Bank Syariah

(Jakarta: Raja Grafindo Persada, 2014).

M. Quraish Shihab, TAFSIR AL-MISHBAH, Pesan, Kesan, dan Keserasian Al-Qur'an Volume 5 (Jakarta: Lentera Hati, 2002)

TAFSIR AL- MISHBAH Pesan, Kesan dan Keserasian Al- Qur'an Volume 14 (Jakarta: Lentera Hati, 2002)

Siregar Syofian, Metode Penelitian Kuantitatif (Jakarta: Kencana Prenada Media Group, 2013).

Sugiono, Metode Penelitian Bisnis (Bandung: Alfabeta, 2005).

Suharsimi Arikunto, Manajemen Penelitian (Jakarta: Rineka Cipta, 2003).

Syahrum \& Sallim, Metodologi Penelitian Kuantitatif (Bandung: Citapustaka Media, 2009)

Tampubolon Manahan P, Manajemen Keuangan (Jakarta: Mitra Wacana Medis, 2013).

Toto Prihadi, Deteksi Cepat Kondisi Keuanga: 7 Analisis Rasio Keuangan (Jakarta: PPM, 2008).

\section{Sumber Lain:}

Amalia Nasuha, "Dampak Kebijakan spin off Terhadap Kinerja Bank Syariah", dalam Jurnal Al-iqtishad, Volume IV, No,2, Juli 2012.

A.Rifin Saptono, "Pemilihan Metode Spin Off Unit Bank Syariah dengan Pendekatan Analisa Faktor ",dalam Jurnal AlMuzara'ah Pemilihan Metode Spin Off Unit Bisnis Syariah.

Atman, "kinerja Bank Konvensional Pasca Spin Off Unit Usaha Syariah", dalam Jurnal 
Keuangan dan Perbankan, Vol 12, No.2, Juni 2016.

Rachmania, Yuliani dan Rasyid, "Analisis Tingkat Kesehatan Bank SyariahSebelum dan Sesudah Spin Off" dalam Jurnal Manajemen dan Bisnis, Volume1, No,1 Februari 2017.

Undang-Undang Nomor 21 Tahun 2008 Tentang Perbankan Syariah Pasal 1 Ayat 32.

Undang-Undang Nomor 40 Tahun 2007 Tentang Perseroan Terbatas Pasal 135.
Peraturan Bank Indonesia Nomor 13/PBI/2013 Pasal 1.

Q.S As-Shaffayat: 4

Q.S At-Taubah, ayat:105.

www.brisyariah.co.id.

www.bri.co.id

www.ojk.go.id 